\title{
Beneficiaries' Willingness to Pay for Resuscitation Provided by Ambulance Attendants: A Survey Using the Contingent Valuation Approach
}

\author{
Yukie Ito $^{1 *}$, Manabu Akahane1, Akie Maeyashiki', Toshio Ogawa², Tomoaki Imamura1 \\ ${ }^{1}$ Department of Public Health, Health Management and Policy, Nara Medical University, Nara, Japan \\ ${ }^{2}$ Department of Health and Welfare and Health Service Management, International University of Health and Welfare, \\ Tokyo, Japan \\ Email: ${ }^{\star}$ yukie@naramed-u.ac.jp
}

How to cite this paper: Ito, Y., Akahane, M., Maeyashiki, A., Ogawa, T. and Imamura, T. (2017) Beneficiaries' Willingness to Pay for Resuscitation Provided by Ambulance Attendants: A Survey Using the Contingent Valuation Approach. Health, 9, 1367-1377.

https://doi.org/10.4236/health.2017.910100

Received: August 2, 2017

Accepted: September 19, 2017

Published: September 22, 2017

Copyright (c) 2017 by authors and Scientific Research Publishing Inc. This work is licensed under the Creative Commons Attribution International License (CC BY 4.0).

http://creativecommons.org/licenses/by/4.0/

(c) (i) Open Access

\begin{abstract}
Background: Japanese emergency medical services (EMS) can be used by anyone for free. Recently, EMS usage has increased; the increased costs and the prolonged time for ambulance transport have become recent social problems. Objective: We surveyed the willingness to pay (WTP) for resuscitation provided by EMS. Methods: In November 2011, men and women (3160) aged 20 59 years were asked to assume that they were experiencing a cardiopulmonary arrest (CPA), and their WTP for EMS services was assessed in the following three situations: Case A, ambulance transport alone; Case B, chest compression in addition to ambulance transport; and Case $\mathrm{C}$, artificial ventilation through chest compression and intratracheal intubation, in addition to ambulance transport. We calculated the mean WTP for each case. Results: The WTP for Case A, B, and C were $¥ 6,696$ (\$65.0), $¥ 16,081$ (\$156.1), and $¥ 27,505$ (\$267.0), respectively. The WTP for Case B was significantly higher in respondents aged 40 - 59 years compared to those aged 20 - 39 years. The WTP for case $\mathrm{B}$ and $\mathrm{C}$ were significantly higher in males compared to females. WTP was significantly lower in students than it was in private employees. Although women's intention to pay was higher than that of men, their WTP was lower than that of men. Public employees' and students' intention to pay was significantly lower than that of private employees. Conclusions: Our study provides information about the optimal fee for EMS, which will be useful for discussions on the feasibility of introducing a fee for EMS in Japan.
\end{abstract}

\section{Keywords}

Emergency Medical Services, Willingness to Pay, Chest Compression, 
Tracheal Intubation, Resuscitation

\section{Introduction}

The number of dispatched ambulances in Japan has been increasing with every consecutive year. In 2016, there were 5,980,000 requests for an ambulance throughout Japan, which means that an ambulance was dispatched once every 5.3 seconds [1]. Each year, more than one hundred thousand patients with cardio pulmonary arrest (CPA) are transported to an emergency hospital in an ambulance [2]. There are three crews members, with at least one emergency life-saving technician, in an ambulance. Emergency life-saving technicians are specially educated and trained to provide an advanced level of emergency care [3] [4] [5]. Therefore, patients can be transported to a hospital while they receive primary care from the ambulance attendants, such as resuscitation maneuvers like artificial ventilation through chest compression and intratracheal intubation [6] [7] [8].

Although, the Japanese emergency medical services (EMS) are available, as a public service, for a person who requires ambulance transport to a medical institution urgently, approximately half of the patients who were actually transported to a hospital by ambulance had mild only symptoms [9]. Further, there has been an increase in the number of the cases in which a person with mild symptoms was transported to the hospital in an ambulance, especially in the metropolitan area of Japan. Additionally, some individuals called for an ambulance because they had no other means of transportation [10]. Consequently, the time taken to arrive at the hospital has increased with each consecutive year, which has become a serious social problem.

Irrespective of the severity of symptoms, a person can take advantage of the ambulance service, without any charge, by calling 119, since the EMS provided by the fire department are run by each of the cities, towns, and villages, and the operating costs are supported by taxes and national government subsidies. However, it is becoming difficult for many local governments such as local cities, towns, and villages to secure adequate revenue owing to the decrease in tax revenue due to the increasing elderly population, decreased working-age population, and stagnant economy. Currently, the total population of Japan is declining, while it is estimated that the elderly population will increase until 2047 [11], with a concomitant increase in the number of users of EMS [12].

Therefore, people seem to be aware that they may have to pay for the use of ambulances in the future. The cost of operating the EMS will become a serious concern in the near future. Based on the current situation, the Ministry of Finance Japan and the Fire and Disaster Management Agency are aware of the necessity to examine the feasibility of introducing a fee for EMS [13]. However, only a few studies have examined users' intention to pay and willingness to pay 
(WTP) for EMS [14] [15] [16]. Therefore, more information is required so that the feasibility of introducing a fee for EMS can be discussed. To this end, the present study examined the WTP for EMS, including ambulance transport and resuscitation maneuvers, to provide basic information for discussions on introducing a fee for EMS in Japan.

\section{Methods}

\subsection{Subjects and Survey Method}

We conducted an Internet panel survey through a company in November 2011. All respondents were registered as panel members with the company. First, to recruit the respondents for the present study, the survey company created a list by random sampling from all registers. Next, an email asking whether they were interested in participating in our survey was sent to all individuals on this list. The registration was closed when the number of respondents in each group reached the target sample size. Then, an Internet-based questionnaire using the contingent valuation approach (CVA) was filled by persons aged $20-59$ years who were registered as panel members with the company. The respondents completed and transmitted their responses via mail. Inclusion and Exclusion criteria are shown in Table 1.

\subsection{Contents of the Survey}

The subjects were asked about their age, sex, household structure, occupation, and their history of attending a cardiopulmonary resuscitation (CPR) training course [how to perform chest compressions, how to use automated external defibrillator (AED), and how to perform artificial ventilation]. Furthermore, they were asked about the WTP in the three cases shown in Table 2, "assuming that they had a cardiopulmonary arrest (CPA)".

\subsection{Calculation of WTP}

The exchange rate of the yen to US dollar in this study was, 103.0 JPY (¥) $=1.00$ USD (as on September 2, 2016). Numbers with upper and lower limits of $0.5 \%$ of WTP values in all 3 cases were excluded from the calculation. The respondents who entered $¥ 0$ into all the fields for Cases A, B, and C were not included in the calculation of the WTP, since it was judged that they had no intention to pay for the EMS. The mean WTP for each case was calculated according to sex, age category (20s - 30s and 40s - 50s), occupation, and history of attending a CPR training course.

Table 1. Inclusion and exclusion criteria.

$\begin{array}{ccl}\begin{array}{c}\text { Inclusion } \\ \text { criteria }\end{array} & \checkmark & \begin{array}{l}\text { Men and women aged } 20-59 \text { years old who were registered with the } \\ \text { Internet panel survey company. }\end{array} \\ \begin{array}{c}\text { Exclusion } \\ \text { criteria }\end{array} & \checkmark & \text { Medical workers such as physicians, nurses, and ambulance attendants. } \\ & \checkmark & \text { Respondents with unknown occupation. }\end{array}$


Table 2. Questionnaire.

\begin{tabular}{|c|c|}
\hline Question & $\begin{array}{l}\text { Currently the costs necessary for ambulance transport and life support that } \\
\text { are provided by the emergency services are not demanded from the user. } \\
\text { Please specify the amount that you would pay for each case if you had to pay } \\
\text { these costs. Please enter "0" if it is unlikely that you would pay for the costs. }\end{array}$ \\
\hline Case A & $\begin{array}{l}\text { Please assume that you had } \mathrm{CPA}^{\mathrm{a}} \text { suddenly. Immediately, you would be } \\
\text { transported to a hospital via an ambulance with ambulance attendants. } \\
\text { However, no critical care would be provided in the ambulance and only } \\
\text { ambulance transport to a hospital would be conducted. }\end{array}$ \\
\hline Case B & $\begin{array}{l}\text { Generally, a patient with CPA is more likely to die within several minutes } \\
\text { when no procedure is provided. However, it has been reported that the } \\
\text { survival rate is improved when a chest compression is provided. In Case B, } \\
\text { chest compression as critical care would be provided by ambulance attendants } \\
\text { in the ambulance during ambulance transport. (ambulance transport and } \\
\text { chest compression) }\end{array}$ \\
\hline Case C & $\begin{array}{l}\text { On the other hand, as critical for the care for some patients with CPA, an air } \\
\text { passage may be secured by inserting a tube into the airway directly, in } \\
\text { combination with mechanical ventilation to deliver oxygen artificially. This } \\
\text { procedure may improve the survival rate to some extent, although it has been } \\
\text { reported that the rate may not be changed by the procedure, and it remains } \\
\text { controversial. In Case C, ambulance attendants would provide critical care by } \\
\text { mechanical ventilation, by using devices in addition to chest compression. } \\
\text { (ambulance transport and mechanical ventilation through chest compression } \\
\text { and intratracheal intubation) }\end{array}$ \\
\hline
\end{tabular}

${ }^{\mathrm{a}} \mathrm{CPA}$ : Cardiopulmonary arrest.

\subsection{Statistical Analysis}

Statistical analyses were conducted to examine the differences in WTP using a t-test or Welch's t-test as appropriate for age category, sex, and experience of attending a CPR training course. Differences according to occupation were also analyzed. For the difference of the means among the occupations, we conducted the Kruskal-Wallis test followed by the Steel's test for multiple comparisons, using the data of private employees as a control.

A logistic regression analysis was carried out to investigate the tendency of WTP for the use of EMS. The intention of presence or absence to pay for using EMS was the dependent variable. The independent variables included sex, age, occupation, and experience of a CPR training course. People who answered $¥ 0$ for all three cases were classified as those who did not intend to pay for the use of EMS and those who responded to any one of the three cases were classified as those who intended to pay. JMP ${ }^{\circledR}$ version 11.2 (SAS Institute Inc., Cary, NC, USA) was used for the analyses. The level of significance was set at $P<0.05$.

\section{Results}

\subsection{Response Rate}

The response rate for the current internet survey was $32.8 \%$; responses were received from 3160 people. Of those, 352 medical workers, such as physicians, nurses, and ambulance attendants, were excluded according to the exclusion 
criteria. The data of 28 subjects at the extreme top or bottom $0.5 \%$, and 55 subjects whose occupation was unknown, were also excluded. Finally, the responses of 2725 subjects were included in the present analysis.

\subsection{Basic Characteristics of Subjects}

Table 3 shows the basic characteristics of the 2725 subjects, according to age category, sex, occupation, and history of attending a CPR training course. The number of respondents who entered $¥ 0$ into all the fields of the WTP was 1246 $(45.7 \%)$.

Table 3. Characteristics of the study group.

\begin{tabular}{|c|c|c|c|}
\hline Category & Classification & $\begin{array}{c}\text { No. of } \\
\text { Respondents }\end{array}$ & $\%$ \\
\hline \multirow[t]{2}{*}{ Age category } & $20-39$ years old & 1289 & 47.3 \\
\hline & 40 - 59 years old & 1436 & 52.7 \\
\hline \multirow[t]{2}{*}{ Sex } & Male & 1346 & 49.4 \\
\hline & Female & 1379 & 50.6 \\
\hline \multirow[t]{8}{*}{ Household structure } & Live alone & 444 & 16.3 \\
\hline & Live with spouse & 492 & 18.1 \\
\hline & Live with spouse and children & 908 & 33.3 \\
\hline & Live with parents & 263 & 9.7 \\
\hline & Live with parents, brothers and sisters & 215 & 7.9 \\
\hline & Live with parents, spouse and children & 172 & 6.3 \\
\hline & Live with parents and children & 98 & 3.6 \\
\hline & Other & 133 & 4.9 \\
\hline \multirow[t]{9}{*}{ Occupation } & Private employee & 1250 & 45.9 \\
\hline & Public employee & 202 & 7.4 \\
\hline & Technical specialist & 16 & 0.6 \\
\hline & Self-employed people & 175 & 6.4 \\
\hline & Free-lancer & 76 & 2.8 \\
\hline & Part-time worker & 232 & 8.5 \\
\hline & Student & 89 & 3.3 \\
\hline & Housewife/Housekeeping husband & 539 & 19.8 \\
\hline & Unemployed & 146 & 5.4 \\
\hline Experience of attending & No & 1551 & 56.9 \\
\hline $\mathrm{CPR}^{\mathrm{a}}$ training course & Yes & 1174 & 43.1 \\
\hline \multirow[t]{2}{*}{$\begin{array}{c}\text { Intention to pay for the } \\
\text { EMS }\end{array}$} & No & 1246 & 45.7 \\
\hline & Yes & 1479 & 54.3 \\
\hline
\end{tabular}

${ }^{\mathrm{a}} \mathrm{CPR}$ : Cardiopulmonary resuscitation. 


\subsection{Distribution of WTP}

Figure 1 shows the percentages of WTP for the three cases. The number of respondents who answered $¥ 0$ was the largest in Case $\mathrm{A}$, followed by Case B, and the smallest was in Case C. Conversely, the percentage of the respondents who answered $¥ 10,000$ (\$97.1) or more increased from A to C.

\subsection{WTP According to Various Groups}

Table 4 shows the mean WTP of the 1479 respondents who indicated the intention to pay for resuscitation, according to age category, sex, occupation, and history of attending a CPR training course. The WTP increased from A to B. A significant difference based on sex was observed in Case B and C, and in Case B
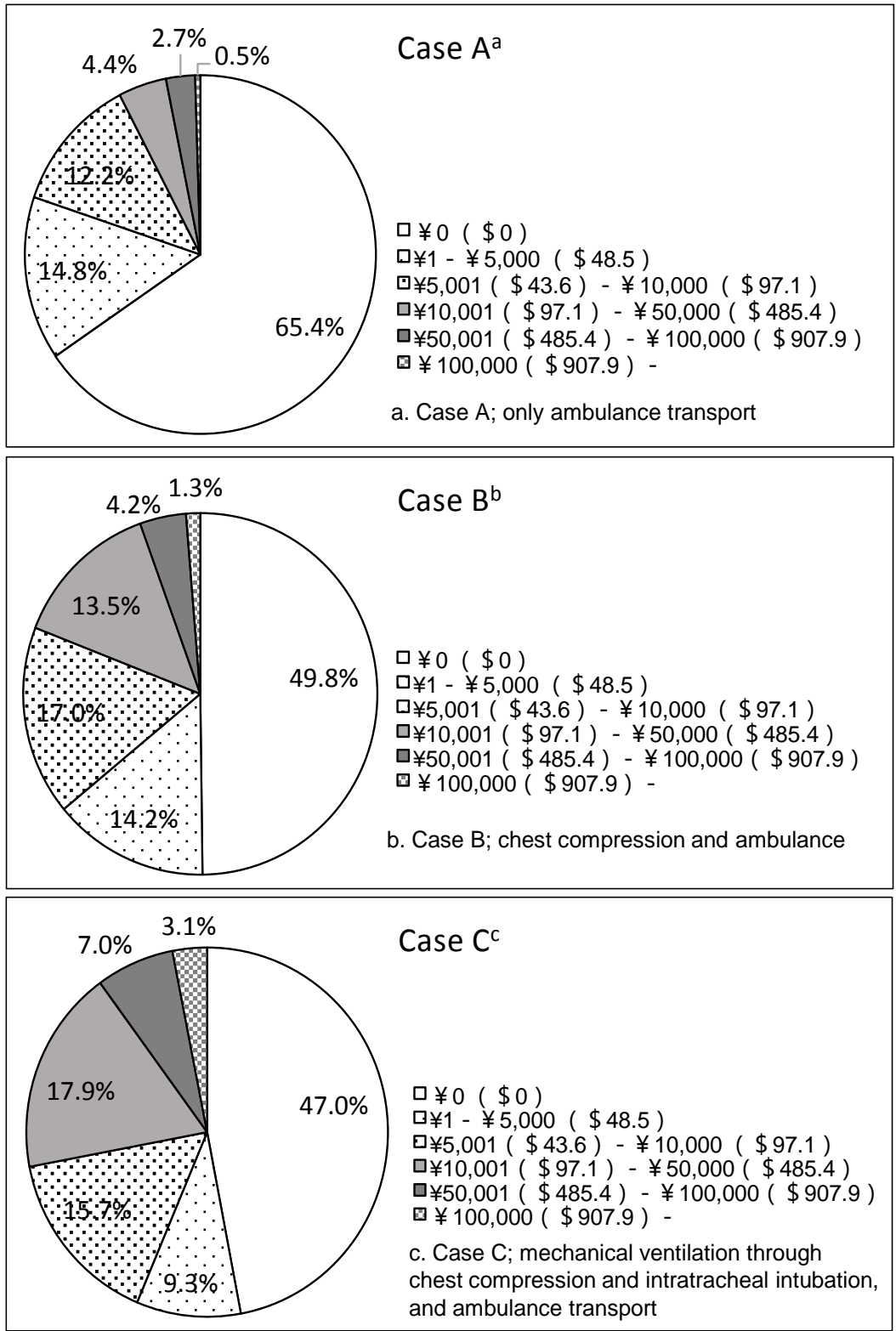

Figure 1. Distribution of WTP. 
Table 4. WTP of the respondents who indicated their intention to pay for EMS.

\begin{tabular}{|c|c|c|c|c|c|c|c|}
\hline \multirow{3}{*}{ Category } & \multirow{3}{*}{ Classification } & \multicolumn{6}{|c|}{ WTP } \\
\hline & & \multicolumn{2}{|c|}{ Case $\mathrm{A}^{\mathrm{a}}$} & \multicolumn{2}{|c|}{ Case $\mathrm{B}^{\mathrm{b}}$} & \multicolumn{2}{|c|}{ Case $C^{c}$} \\
\hline & & JPY & $\left(\mathrm{USD}^{\mathrm{d}}\right)$ & JPY & (USD) & JPY & (USD) \\
\hline \multirow[t]{2}{*}{ Age category } & $20-39$ years old & 6853 & $(66.5)$ & 13,692 & (132.9) & 26,032 & $(252.7)$ \\
\hline & 40 - 59 years old & 8733 & $(84.8)$ & 19,719 & $(191.4)^{\star}$ & 31,009 & $(301.1)$ \\
\hline \multirow[t]{2}{*}{ Sex } & Male & 9043 & $(87.8)$ & 20,160 & $(195.7)$ & 32,920 & $(319.6)$ \\
\hline & Female & 6672 & $(64.8)$ & 13,655 & $(132.6)^{\dagger}$ & 24,491 & $(237.8)^{\dagger}$ \\
\hline \multirow[t]{9}{*}{ Occupation } & Private employee & 9954 & $(96.6)$ & 17,370 & $(168.6)$ & 28,582 & (277.5) \\
\hline & Public employee & 6032 & $(58.6)$ & 11,916 & $(115.7)$ & 20,111 & (195.3) \\
\hline & Technical specialist & 2313 & $(22.5)$ & 9,751 & $(94.7)$ & 16,126 & (156.6) \\
\hline & Self-employed people & 6216 & $(60.4)$ & 19,119 & $(185.6)$ & 41,569 & $(403.6)$ \\
\hline & Free-lancer & 6092 & $(59.1)$ & 18,895 & (183.4) & 23,263 & $(225.9)$ \\
\hline & Part-time worker & 5834 & $(56.6)$ & 22,065 & $(214.2)$ & 33,555 & $(325.8)$ \\
\hline & Student & 1921 & $(18.7)^{\ddagger}$ & 5713 & $(55.5)^{\ddagger}$ & 12,697 & $(123.3)^{\ddagger}$ \\
\hline & Housewife/Housekeeping husband & 6176 & $(60.0)$ & 15,647 & $(151.9)$ & 27,132 & $(263.4)$ \\
\hline & Unemployed & 8706 & $(84.5)$ & 19,500 & $(189.3)$ & 37,360 & $(362.7)$ \\
\hline $\begin{array}{l}\text { Experience of } \\
\text { attending }\end{array}$ & No & 7201 & $(69.9)$ & 16,023 & $(155.6)$ & 27,358 & $(265.6)$ \\
\hline $\begin{array}{l}\text { CPR training } \\
\text { course }\end{array}$ & Yes & 8692 & $(84.4)$ & 17,985 & $(174.6)$ & 30,367 & $(294.8)$ \\
\hline Mean & & 6696 & $(65.0)$ & 16,081 & (156.1) & 27,505 & $(267.0)$ \\
\hline
\end{tabular}

${ }^{a}$ Case A: only ambulance transport. ${ }^{b}$ Case B: chest compression and ambulance transport. ${ }^{c}$ Case C: mechanical ventilation through chest compression and intratracheal intubation, and ambulance transport. ${ }^{\mathrm{d}} \mathrm{US}$ dollar to Japanese yen convert rate; $1 \mathrm{USD}=103.0 \mathrm{JPY}$ as of September $2,2016 .{ }^{\star}, \dagger, \ddagger$ indicate $P<$

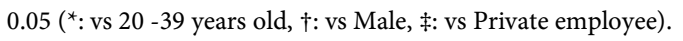

according to age category. According to occupation, the WTP was significantly lower in students as compared to that in private employees, in all cases.

\subsection{Users' Intention to Pay for the Use of Ambulance and Attributes}

Table 5 shows the result of intention to pay. Students were least likely to express WTP in all the three groups. As respondents' age increased, the intention to pay increased; the odds ratio for men, public employees, and students were low.

\section{Discussion}

Our study indicated that more than half of the respondents expressed an intention to pay for EMS. The total sum of WTP increased when it was indicated in the survey that resuscitation was needed in addition to ambulance transport. The amount of WTP for each case was significantly different between men and women. Women's intention to pay was higher, while their payment amount for the WTP tended to be lower than that of men. This difference may be because the number of people involved in paid employment is generally smaller in women than that in men [17]. Additionally, there is a difference in the average yearly income of men and women [18]. Consequently, such sex differences in WTP may be revealed. Our results also showed that public employees and 
Table 5. A logistic regression with the presence or absence of the intention to pay for critical care and with age, sex, occupation, and experience of attending a CPR training course as independent variables.

\begin{tabular}{|c|c|c|c|c|c|c|c|c|c|}
\hline \multirow[t]{2}{*}{ Independent variable } & \multicolumn{3}{|c|}{ CaseA $^{a}$} & \multicolumn{3}{|c|}{ CaseB $^{\mathrm{b}}$} & \multicolumn{3}{|c|}{ CaseC $^{c}$} \\
\hline & $\mathrm{OR}^{\mathrm{d}}$ & $\left(95 \% \mathrm{CI}^{\mathrm{e}}\right)$ & $P$ & OR & $(95 \% \mathrm{CI})$ & $P$ & OR & $(95 \% \mathrm{CI})$ & $P$ \\
\hline Age & 1.008 & $(1.000-1.017)$ & 0.043 & 1.009 & $(1.001-1.017)$ & 0.026 & 1.008 & $(1.001-1.016)$ & 0.034 \\
\hline \multicolumn{10}{|l|}{ Sex } \\
\hline Female & & reference & & & reference & & & reference & \\
\hline Male & 0.998 & $(0.851-1.170)$ & 0.978 & 0.838 & $(0.721-0.975)$ & 0.022 & 0.807 & $(0.693-0.939)$ & 0.006 \\
\hline \multicolumn{10}{|l|}{ Occupation } \\
\hline Private employee & & reference & & & reference & & & reference & \\
\hline Public employee & 0.866 & $(0.626-1.189)$ & 0.376 & 0.712 & $(0.525-0.965)$ & 0.028 & 0.700 & $(0.516-0.948)$ & 0.021 \\
\hline Technical specialist & 0.787 & $(0.246-2.181)$ & 0.655 & 0.902 & $(0.329-2.472)$ & 0.838 & 0.815 & $(0.297-2.235)$ & 0.685 \\
\hline Self-employed people & 1.122 & $(0.806-1.554)$ & 0.492 & 1.086 & $(0.787-1.501)$ & 0.616 & 1.101 & $(0.797-1.527)$ & 0.562 \\
\hline Free-lancer & 0.666 & $(0.389-1.094)$ & 0.114 & 0.827 & $(0.517-1.318)$ & 0.425 & 0.790 & $(0.495-1.260)$ & 0.321 \\
\hline Part-time worker & 0.744 & $(0.545-1.006)$ & 0.055 & 0.772 & $(0.582-1.023)$ & 0.072 & 0.783 & $(0.591-1.038)$ & 0.089 \\
\hline Student & 0.232 & $(0.106-0.449)$ & $<0.01$ & 0.486 & $(0.297-0.778)$ & 0.002 & 0.553 & $(0.345-0.874)$ & 0.011 \\
\hline $\begin{array}{c}\text { Housewife/ } \\
\text { Housekeeping husband }\end{array}$ & 1.110 & $(0.899-1.368)$ & 0.332 & 0.966 & $(0.788-1.185)$ & 0.741 & 0.972 & $(0.792-1.194)$ & 0.789 \\
\hline Unemployed & 0.683 & $(0.462-0.992)$ & 0.045 & 0.863 & $(0.611-1.219)$ & 0.404 & 0.869 & $(0.616-1.229)$ & 0.427 \\
\hline
\end{tabular}

Experience of attending $\mathrm{CPR}^{\mathrm{f}}$ training course

\begin{tabular}{lccccccccc} 
No & \multicolumn{3}{c}{ reference } & \multicolumn{3}{c}{ reference } & & \multicolumn{3}{c}{ reference } \\
Yes & 0.962 & $(0.815-1.134)$ & 0.642 & 1.009 & $(0.863-1.181)$ & 0.908 & 1.045 & $(0.893-1.222)$ & 0.587
\end{tabular}

${ }^{a}$ Case A: only ambulance transport. ${ }^{b}$ Case B: chest compression and ambulance transport. ${ }^{c}$ Case C: mechanical ventilation through chest compression and intratracheal intubation, and ambulance transport. ${ }^{\mathrm{d}}$ odds ratio. ${ }^{\mathrm{e}} \mathrm{Confidence} \mathrm{interval.}{ }^{\mathrm{f}} \mathrm{Cardiopulmonary}$ resuscitation.

students were less likely to express the intention to pay. It is interesting that public employees' intention to pay for EMS was lower than that of private employees. These results may be derived from public employees' awareness that the services should naturally be funded by public money, because EMS staff are also public employees.

Only a few studies have reported the percentage of intention to pay for EMS using questionnaires in Japan. A survey conducted in a metropolitan area showed that $63 \%$ of the respondents thought that the user of the ambulance should pay for EMS use, at least in part [14]. Another survey on patients who had undergone an examination in the emergency unit of a hospital reported that $73 \%$ of the respondents agreed that patients should be charged for an ambulance [15]. Compared to these reports, the percentage of respondents who expressed the intention to pay was lower in our study. This may be because the previous study [15] was conducted immediately after their use of ambulance transport and emergency care. Consequently, the percentage of the respondents who answered in the affirmative, regardless of the fee for the ambulance, might have been higher.

In a survey conducted in metropolitan areas in Japan, the most common WTP for the use of EMS was $¥ 3000$ (\$29.1) - ¥5000 (\$48.5) [14]. Similarly, in a survey 
conducted in patients who were transported to an emergency hospital, the most common response was $¥ 10,000$ (\$97.1) [15]. The results of our survey [WTP of $¥ 27,505$ ( $\$ 267.0)]$ might be higher than that observed in previous surveys, because the assumed situation in our study was CPA. The respondents in our study were asked about the payable amount for an ambulance if they had a CPA, which is one of the most critical cases among the emergency transports. However, compared to the data from other countries, a total of $¥ 27,505$ ( $\$ 267.0$ ) was not considered a large amount. In some countries outside Japan, the system of charging for ambulance transport has been adopted, and there is a fee structure to distinguish an emergency from a non-emergency; the fee structure is different according to the medical skill of the dispatched crew, and there is an additional fee according to the distance that the ambulance has traveled [19] [20]. In the EMS in New York, when an ambulance is dispatched for a person who requires emergency care for a severe condition, at least $\$ 1000$ (¥103,000) is charged [21].

It should be noted that various factors (such as the psychology or the social situation of the person calling for an ambulance) may influence their decision to call for an ambulance. Another survey (of the WTP by the contingent valuation approach in the situation of a myocardial infarction) revealed that the number of patients who used the EMS did not decrease even if the fee for the ambulance was high [16]. However, according to the original function of the EMS, it is desirable that the costs should be paid using public money for patients requiring the ambulance urgently due to a serious illness.

There are some limitations in this study. First, the study subjects were limited to persons aged 20 - 59 years, which meant that the thoughts of persons younger than 20 years and those aged 60 years or older were not included. Second, this study was a survey of the WTP, in which CPA was assumed to be an extremely serious condition. The results are likely to be different from those of the WTP for ambulance transport for patients with a disease condition that is not serious. Third, this survey was conducted as an Internet questionnaire. This may result in a selection bias of subjects. However, web surveys have recently become a common method of conducting research [22] [23].

\section{Conclusion}

We investigated the WTP for EMS, including ambulance transport and resuscitation, by asking respondents to assume that they were experiencing CPA. The intention to pay for artificial ventilation through chest compression and intratracheal intubation (in addition to ambulance transport) was expressed by $54.3 \%$ of the respondents. Our study provides information about the fee that people are ready to pay for EMS in Japan. This information will be useful for discussions on the feasibility of introducing a fee for EMS in Japan.

\section{References}

[1] Official Statement by Fire and Disaster Management Agency, Government of Japan. 
2014. (In Japanese)

http://www.fdma.go.jp/html/hakusho/h27/h27/html/2-5-1-1.html

[2] SOS-KANTO 2012 Study Group (2015) Changes in Pre- and In-Hospital Management and Outcomes for Out-Of-Hospital Cardiac Arrest between 2002 and 2012 in Kanto, Japan: The SOS-KANTO 2012 Study. Acute Medicine \& Surgery, 2, 225-233. https://doi.org/10.1002/ams2.102

[3] Tanigawa, K. and Tanaka, K. (2006) Emergency Medical Service System in Japan: Past, Present, and Future. Resuscitation, 69, 365-370. PMID: 16740355. https://doi.org/10.1016/j.resuscitation.2006.04.001

[4] Kitamura, T., Iwami, T., Kawamura, T., Nishiyama, C., Sakai, T., Sugihara, K., Sasaki, M., Kajino, K., Irisawa, T., Hayashida, S., Nishiuchi, T. and Hiraide, A. (2014) Ambulance Calls and Prehospital Transportation Time of Emergency Patients with Cardiovascular Events in Osaka City. Acute Medicine \& Surgery, 1, 135-144. https://doi.org/10.1002/ams2.25

[5] Official Statement by Fire and Disaster Management Agency, Government of Japan. 2015. (in Japanese)

http://www.fdma.go.jp/html/hakusho/h27/h27/html/2-5-2-3.html?words=\%E6\%95 \%91\%E6\%80\%A5\%E6\%95\%91\%E5\%91\%BD\%E5\%A3\%AB

[6] Akahane, M., Ogawa, T., Koike, S., Tanabe, S., Horiguchi, H., Mizoguchi, T., Yasunaga, H. and Imamura, T. (2011) The Effects of Sex on Out-Of-Hospital Cardiac Arrest Outcomes. The American Journal of Medicine, 124, 325-333. PMID: 21435423. https://doi.org/10.1016/j.amjmed.2010.10.020

[7] Ogawa, T., Akahane, M., Koike, S., Tanabe, S., Mizoguchi, T. and Imamura, T. (2011) Outcomes of Chest Compression Only CPR versus Conventional CPR Conducted by Lay People in Patients with out of Hospital Cardiopulmonary Arrest Witnessed by Bystanders: Nationwide Population Based Observational Study. BMJ, 342, c7106. PMID: 21273279. https://doi.org/10.1136/bmj.c7106

[8] Akahane, M., Tanabe, S., Ogawa, T., Koike, S., Horiguchi, H., Yasunaga, H. and Imamura, T. (2013) Characteristics and Outcomes of Pediatric Out-Of-Hospital Cardiac Arrest by Scholastic Age Category. Pediatric Critical Care Medicine, 14, 130-136. PMID: 23314182. https://doi.org/10.1097/PCC.0b013e31827129b3

[9] Official Statement by Fire and Disaster Management Agency, Government of Japan. 2014. (In Japanese) http://www.fdma.go.jp/html/hakusho/h27/h27/html/2-5-1-2.html

[10] Camasso-Richardson, K., Wilde, J.A. and Petrack, E.M. (1997) Medically Unnecessary Pediatric Ambulance Transports: A Medical Taxi Service? Academic Emergency Medicine, 4, 1137-1141. PMID: 9408429. https://doi.org/10.1111/j.1553-2712.1997.tb03696.x

[11] Cabinet Office, Government of Japan (2014) Official Statement. (In Japanese) http://www8.cao.go.jp/kourei/whitepaper/w-2015/html/zenbun/s1_1_1.html

[12] Fire and Disaster Management Agency, Government of Japan (2010) Official Statement. (In Japanese) http://www.fdma.go.jp/html/hakusho/h23/h23/html/2-2-4-5_7.html

[13] Fire and Disaster Management Agency, Government of Japan (2006) Official Statement. (In Japanese)

http://www.fdma.go.jp/neuter/topics/houdou/h18/180412-2/180412-2houkoku_03. pdf

[14] Kawakami, C., Ohshige, K., Wada, S., Kawano, T., Hitachi, T., Kubota, K. and Tochikubo, O. (2005) Questionnaire Survey of Ambulance Fee in Yokohama City. 
Japanese Society of Public Health, 52, 809-816. (In Japanese)

[15] Shirako, T., Tsukagawa, T., Inada, S., Yokoe, M., Ishikawa, K., Matsuda, S., Okuda, A., Taira, Y. and Matsuda, S. (2007) For the Appropriate Use of the Ambulance; A Questionnaire Survey of the Patients and Medical Staff. Chuubu Journal of Acute Medicine, 3, 12-16. (In Japanese)

[16] Ohshige, K., Kawakami, C., Kubota, K. and Tochikubo, O. (2005) A Contingent Valuation Study of the Appropriate User Price for Ambulance Service. Academic Emergency Medicine, 12, 932-939. https://doi.org/10.1111/j.1553-2712.2005.tb00803.x

[17] Statistics Bureau, Management Agency of the Ministry of Internal Affairs and Communications, Government of Japan (2013) Official Statement. (In Japanese) http://www.soumu.go.jp/johotsusintokei/whitepaper/ja/h26/html/nc141210.html

[18] Cabinet Office, Government of Japan (2012) Official Statement. (In Japanese) http://www.gender.go.jp/about_danjo/whitepaper/h25/zentai/html/zuhyo/zuhyo0100-23.html

[19] Ambulance Service of New South Wales, Australia. Charge for NSW Residents. http://www.ambulance.nsw.gov.au/Accounts--Fees/Fees-and-Charges.html

[20] Singapore Civil Defence Force, Singapore. SCDF Ambulance Charges. https://www.scdf.gov.sg/content/scdf_internet/en/general/information/information _on_scdfand 1777 medicalservices.html

[21] New York City Fire Department. Schedule of Charge. http://www1.nyc.gov/assets/fdny/downloads/pdf/about/fee-schedule-ambulance.pdf

[22] Akahane, M., Maeyashiki, A., Yoshihara, S., Tanaka, Y. and Imamura, T. (2016) Relationship between Difficulties in Daily Activities and Falling: Loco-Check as a Self-Assessment of Fall Risk. Interactive Journal of Medical Research, 5, e20. https://doi.org/10.2196/ijmr.5590

[23] Sano, T., Akahane, M., Sugiura, H., Ohkusa, Y., Okabe, N. and Imamura, T. (2013) Internet Survey of the Influence of Environmental Factors on Human Health: Environmental Epidemiologic Investigation Using the Web-Based Daily Questionnaire for Health. International Journal of Environmental Health Research, 23, 247-257. https://doi.org/10.1080/09603123.2012.717916

Submit or recommend next manuscript to SCIRP and we will provide best service for you:

Accepting pre-submission inquiries through Email, Facebook, LinkedIn, Twitter, etc. A wide selection of journals (inclusive of 9 subjects, more than 200 journals)

Providing 24-hour high-quality service

User-friendly online submission system

Fair and swift peer-review system

Efficient typesetting and proofreading procedure

Display of the result of downloads and visits, as well as the number of cited articles

Maximum dissemination of your research work

Submit your manuscript at: http://papersubmission.scirp.org/

Or contact health@scirp.org 